\title{
Significance of preoperative C-reactive protein as a parameter in patients with small cell carcinoma of the esophagus
}

This article was published in the following Dove Press journal:

OncoTargets and Therapy

2I August 2013

Number of times this article has been viewed

\section{Ji-Feng Feng \\ Hong-Guang Zhao \\ Jin-Shi Liu \\ Qi-Xun Chen}

Department of Thoracic Surgery, Zhejiang Cancer Hospital, Key Laboratory Diagnosis and Treatment Technology on Thoracic Oncology, Banshan Bridge, Hangzhou, People's Republic of China
Correspondence: ji-Feng Feng Department of Thoracic Surgery, Zhejiang Cancer Hospital, Key Laboratory Diagnosis and Treatment Technology on Thoracic Oncology, No 38 Guangji Road, Banshan Bridge, Hangzhou 310022, People's Republic of China Tel +86 057I 88I 22038 Fax +86 057I 88I2 2038 Email jifzhejiang@gmail.com
Background: C-reactive protein (CRP) is inversely related to prognosis in many cancers, however, no studies regarding the predictive value of CRP in small cell carcinoma of the esophagus (SCCE) are available. The aim of this study was to determine the prognostic value of preoperative CRP in patients with SCCE.

Methods: From January 2001 to December 2010, a retrospective analysis of 43 consecutive patients with SCCE was conducted. Univariate and multivariate analyses were performed to evaluate the prognostic parameters.

Results: In our study, elevated CRP levels $(>10 \mathrm{mg} / \mathrm{L})$ were found in 16 patients $(37.2 \%)$. CRP levels were significantly higher in patients with deeply invasive tumors $(P=0.018)$ and those associated with nodal metastasis $(P=0.018)$. Patients with CRP $\leq 10 \mathrm{mg} / \mathrm{L}$ had a significantly better overall survival than patients with CRP $>10 \mathrm{mg} / \mathrm{L}(25.9 \%$ vs $6.3 \%$, $P=0.004)$. Multivariate analyses showed that CRP was a significant predictor for overall survival. CRP $>10 \mathrm{mg} / \mathrm{L}$ had a hazard ratio of 2.756 (95\% confidence interval: $1.115-6.813$, $P=0.028$ ) for overall survival.

Conclusion: Preoperative CRP is an independent predictive factor for long-term survival in patients with SCCE.

Keywords: C-reactive protein, esophageal cancer, small cell carcinoma, survival

\section{Introduction}

Small cell carcinoma of the esophagus (SCCE) is a rare disease, which was first described in 1952 by McKeown. ${ }^{1}$ The incidence of SCCE within all esophageal cancers (ECs) is $0.05 \%-2.4 \%$ in Western populations, and this rate rises up to $7.6 \%$ in Chinese and Japanese literature. ${ }^{2,3}$ Previous studies suggested that SCCE is a highly aggressive disease with poor prognosis. ${ }^{3}$ Although advances have occurred in multidisciplinary treatment, the 5-year survival in SCCE is still poor. Therefore, assessing the prognostic factors in SCCE patients will become more and more important.

Recently, there has been increasing evidence that a systemic inflammatory response is of prognostic value in various cancers. ${ }^{4,5} \mathrm{C}$-reactive protein (CRP) is an index of systemic inflammation. Recent publications have suggested that preoperative CRP is inversely related to prognosis in many cancers; a high level is associated with poor prognosis. ${ }^{6,7}$ Furthermore, a few recent studies investigated the value of CRP levels in patients with EC and obtained encouraging results in terms of prognosis prediction. ${ }^{8-10}$ However, to the best of our knowledge, no studies regarding the predictive value of CRP in SCCE are available. Therefore, the aim of this study was to determine the prognostic value of CRP in patients with SCCE. 


\section{Materials and methods Patients}

From January 2001 to December 2010, a retrospective analysis was conducted of 43 patients with SCCE who underwent curative esophagectomy at Zhejiang Cancer Hospital (Hangzhou, People's Republic of China). All of the patients included in the analysis fit the following criteria: (1) SCCE confirmed by histopathology; (2) limited disease without distal metastasis; (3) curative esophagectomy with margins free of disease. Based on the medical records, the following data were collected for each patient: age, gender, tumor length, tumor location, preoperative CRP, depth of invasion, nodal metastasis, treatment, and other miscellaneous characteristics.

All of the above patients were followed up by posting letters or by telephone interviews. The last follow-up was November 30, 2011. All subjects gave written informed consent to the study protocol, which was approved by the Ethical Committees of Zhejiang Cancer Hospital, Hangzhou, People's Republic of China.

\section{Preoperative CRP measurement}

Data on preoperative CRP were extracted in a retrospective fashion from the medical records. All blood test results were taken within 1 week prior to surgery. Serum CRP was determined by latex-enhanced homogeneous immunoassay (wide-range) (Hitachi 917; Skill, Munich, Germany). Normal values provided by the manufacturer were lower than $10 \mathrm{mg} / \mathrm{L}$.

\section{Adjuvant chemoradiotherapy}

Adjuvant chemoradiotherapy was used in 26 cases. Among them, 13 cases were treated with four to six courses of platinum-based combination chemotherapy, eight cases with radiotherapy, and five cases with chemoradiotherapy, respectively. For chemotherapy, eight patients were treated with etoposide plus cisplatin, three with paclitaxel plus cisplatin, and one with 5-fluorouracil plus platinum. For radiotherapy, radiation was delivered from 2 Gy per day, 5 days per week, to a total dose of 45-68 Gy. No patients were treated with neoadjuvant.

\section{Statistical analysis}

Statistical evaluation was conducted with SPSS (v17.0; SPSS Inc, Chicago, IL, USA). The patients were divided into two groups according to the CRP measured preoperatively: those with CRP values in the normal range ( $\leq 10 \mathrm{mg} / \mathrm{L})$ and those with elevated CRP levels $(>10 \mathrm{mg} / \mathrm{L})$. The Pearson
Chi-squared test was used to determine the significance of differences between the two groups. The overall cumulative probability of survival was calculated by the Kaplan-Meier method, and the difference was assessed by the log-rank test. A univariate analysis was used to examine the association between various prognostic predictors and survival. Possible prognostic factors associated with overall survival were considered in a multivariable Cox proportional hazards regression analysis (Enter). Hazard ratios (HR) with 95\% confidence intervals (CI) were used to quantify the strength of the association between predictors and survival. A $P$-value less than 0.05 was considered to be statistically significant.

\section{Results}

The baseline characteristics are shown in Table 1. Among the 43 patients, 13 (30.2\%) were women and $30(69.8 \%)$ were men. The mean age was $58.7 \pm 7.8$ years, with an age range of 45-74 years.

There were no significant differences between the two groups in terms of age, gender, tumor location, tumor length, or vessel involvement. However, CRP levels were significantly higher in patients with deeply invasive tumors (T3-4a vs T1-2, $P=0.018$ ) and those associated with nodal metastasis (positive vs negative, $P=0.018$ ) (Table 2).

Univariate analyses were performed using the KaplanMeier method to assess the predictive capability of each variable assessed. Multivariate analyses were then performed with the Cox proportional hazards model. In that

Table I The baseline characteristics of 43 patients with SCCE

\begin{tabular}{ll}
\hline & Cases $(\mathbf{n}, \%)$ \\
Age (mean \pm SD, years) & $58.7 \pm 7.8$ \\
Gender & \\
Female & $13(30.2)$ \\
Male & $30(69.8)$ \\
Tumor size (mean \pm SD, cm) & $4.1 \pm 1.9$ \\
Tumor location & \\
Upper & $2(4.7)$ \\
Middle & $23(53.5)$ \\
Lower & $18(41.8)$ \\
Depth of invasion & \\
TI & $9(20.9)$ \\
T2 & $10(23.3)$ \\
T3 & $22(5 I .1)$ \\
T4 & $2(4.7)$ \\
Nodal metastasis & \\
N0 & $15(34.9)$ \\
NI & $13(30.2)$ \\
N2 & $8(18.6)$ \\
N3 & $7(16.3)$ \\
\hline
\end{tabular}

Abbreviations: SCCE, small cell carcinoma of the esophagus; SD, standard deviation. 
Table 2 The characteristics between patients with $\mathrm{CRP} \leq 10 \mathrm{mg} / \mathrm{L}$ and $>10 \mathrm{mg} / \mathrm{L}$

\begin{tabular}{|c|c|c|c|}
\hline & $\begin{array}{l}\text { CRP } \leq 10 \mathrm{mg} / \mathrm{L} \\
(\mathrm{n}, \%)\end{array}$ & $\begin{array}{l}\text { CRP }>10 \mathrm{mg} / \mathrm{L} \\
(\mathrm{n}, \%)\end{array}$ & $P$-value \\
\hline Age (years) & & & 0.965 \\
\hline$\leq 60$ & $15(55.6)$ & $9(56.3)$ & \\
\hline$>60$ & $12(44.4)$ & $7(43.7)$ & \\
\hline Gender & & & 0.086 \\
\hline Female & II (40.7) & $2(12.5)$ & \\
\hline Male & $16(59.3)$ & $14(87.5)$ & \\
\hline Tumor length $(\mathrm{cm})$ & & & 0.278 \\
\hline$\leq 3.0$ & $13(48.1)$ & $5(3 \mid .3)$ & \\
\hline$>3.0$ & $14(5 \mid .9)$ & II (68.7) & \\
\hline Tumor location & & & 0.141 \\
\hline Upper/middle & I8 (66.7) & $7(43.7)$ & \\
\hline Lower & $9(33.3)$ & $9(56.3)$ & \\
\hline Vessel involvement & & & 0.719 \\
\hline Negative & $20(74.1)$ & $13(81.3)$ & \\
\hline Positive & 7 (25.9) & $3(18.7)$ & \\
\hline Depth of invasion & & & 0.018 \\
\hline TI-2 & $15(55.6)$ & $3(18.7)$ & \\
\hline T3-4a & $12(44.4)$ & $13(81.3)$ & \\
\hline Nodal metastasis & & & 0.018 \\
\hline Negative & $13(48.1)$ & $2(12.5)$ & \\
\hline Positive & I4 (5|.9) & I4 (87.5) & \\
\hline
\end{tabular}

Abbreviation: CRP, C-reactive protein.

model, we demonstrated that CRP (HR: 2.756, 95\% CI: $1.115-6.813, P=0.028$ ), and chemoradiotherapy (HR: $0.294,95 \%$ CI: $0.129-0.673, P=0.004)$ were independent prognostic factors (Table 3 ). In addition, patients with $\mathrm{CRP} \leq 10 \mathrm{mg} / \mathrm{L}$ had a significantly better overall survival than patients with $\mathrm{CRP}>10 \mathrm{mg} / \mathrm{L}(25.9 \%$ vs $6.3 \%$, $P=0.004)$ (Figure 1).

\section{Discussion}

To the best of our knowledge, this is the first study to determine the prognostic value of preoperative CRP in predicting the prognosis for patients with SCCE. Our study showed that preoperative CRP is an independent predictive factor for long-term survival in patients with SCCE (HR: 2.756, 95\% CI: $1.115-6.813, P=0.028$ ).

The standard therapy for SCCE has not been yet established. Because of the rarity of SCCE, prospective, randomized controlled trials of its optimal treatment are unlikely. The histology and clinical characteristics of SCCE are similar to small cell carcinoma of the lung (SCCL); subsequently, investigations have recommended that a multimodal approach be used for SCCE as it is for SCCL. ${ }^{11}$ The most commonly used regimens include platinum-based agents, which are often used for SCCL. ${ }^{12}$ However, the optimal radiation dose for SCCE has not been established. For patients with limited disease, there were several reports showing that long-term survival of SCCE was achieved after esophagectomy with or without adjuvant chemotherapy. ${ }^{13,14}$

There is a strong link between inflammation and cancer. It is well known that cancer promotes the release of proinflammatory cytokines from tumor cells. The cytokines interact with the immunovascular system and facilitate growth, invasion, and metastasis. ${ }^{4,5}$ Recent studies have shown that elevated preoperative serum CRP levels may be associated with tumor size, depth of invasion, and nodal metastasis, resulting in poor prognosis in patients with various cancers, including EC. ${ }^{6,79}$ Thus, in our study, we wanted to determine whether preoperative CRP level is associated with overall survival after esophagectomy for SCCE.

Our results demonstrated that CRP levels were significantly higher in patients with deeply invasive tumors $(P=0.018)$ and those associated with nodal metastasis $(P=0.018)$. This observation is in line with data from Shimada et $\mathrm{al}^{8}$ and Nozoe et al, ${ }^{9}$ but is contrary to the result of Guillem et al, ${ }^{10}$ who suggested that preoperative CRP is not significantly correlated with the above clinicopathological factors. However, in our study, no relationship was found between CRP level and tumor size.

A number of studies have shown that increased preoperative CRP levels in various solid tumors are associated with poor prognosis. ${ }^{6,7}$ Shimada et al ${ }^{8}$ demonstrated that although the difference in survival was mainly attributable to differences in TNM staging between the low and high CRP groups, preoperative CRP was an independent prognostic factor according to multivariate analysis. In our study, the survival of patients in the high CRP group $(>10 \mathrm{mg} / \mathrm{L})$ was significantly worse than that of the low CRP group $(\leq 10 \mathrm{mg} / \mathrm{L}$; $25.9 \%$ vs $6.3 \%, P=0.004)$. In addition, preoperative CRP was an independent prognostic factor according to multivariate analysis $(P=0.028)$.

The reasons why CRP levels can be correlated with prognosis in cancer patients remain to be determined. Any explanation of accumulating data showing that serum CRP is involved in host defenses against infections as highlighted by murine transgenic models must be speculative. ${ }^{15-17}$ As with other proteic markers of acute inflammation, CRP has several biological functions including complement activation through the classical pathway, opsonization, leukocyte chemotactism, and platelet activation. ${ }^{18,19}$

The potential limitations of the present study include the relatively small number of patients, as well as the fact that the analysis was retrospective, and the short mean follow-up duration. Furthermore, due to the limited number of patients with SCCE, our analysis may suffer from type I or 
Table 3 Univariate and multivariate analyses of overall survival in SCCE patients

\begin{tabular}{|c|c|c|c|c|c|}
\hline & Survival (\%) & Chi-square & $P$-value & HR (95\% Cl) & $P$-value \\
\hline Age (years) & & 0.686 & 0.408 & & \\
\hline$\leq 60$ & 16.7 & & & & \\
\hline$>60$ & 21.1 & & & & \\
\hline Gender & & $1.84 \mid$ & 0.175 & & \\
\hline Female & 38.5 & & & & \\
\hline Male & 10.0 & & & & \\
\hline Tumor length $(\mathrm{cm})$ & & 6.846 & 0.009 & & 0.582 \\
\hline$\leq 3$ & 33.3 & & & 1.000 & \\
\hline$>3$ & 8.0 & & & $1.267(0.546-2.937)$ & \\
\hline Tumor location & & 0.024 & 0.877 & & \\
\hline Upper/middle & 20.0 & & & & \\
\hline Lower & 16.7 & & & & \\
\hline CRP (mg/L) & & 8.115 & 0.004 & & 0.028 \\
\hline$\leq 10$ & 25.9 & & & 1.000 & \\
\hline$>10$ & 6.3 & & & $2.756(1.115-6.813)$ & \\
\hline Vessel involvement & & 1.068 & 0.301 & & \\
\hline Negative & 21.2 & & & & \\
\hline Positive & 10.0 & & & & \\
\hline Depth of invasion & & 7.433 & 0.006 & & 0.232 \\
\hline TI-2 & 33.3 & & & 1.000 & \\
\hline T3-4a & 8.0 & & & $1.716(0.708-4.161)$ & \\
\hline Nodal metastasis & & 9.687 & 0.002 & & 0.189 \\
\hline Negative & 40.0 & & & 1.000 & \\
\hline Positive & 7.1 & & & I.89। (0.73।-4.892) & \\
\hline Chemoradiotherapy & & 5.577 & 0.018 & & 0.004 \\
\hline No & 5.9 & & & 1.000 & \\
\hline Yes & 26.9 & & & $0.294(0.129-0.673)$ & \\
\hline
\end{tabular}

Abbreviations: $\mathrm{Cl}$, confidence interval; CRP, C-reactive protein; HR, hazard ratio; SCCE, small cell carcinoma of the esophagus.

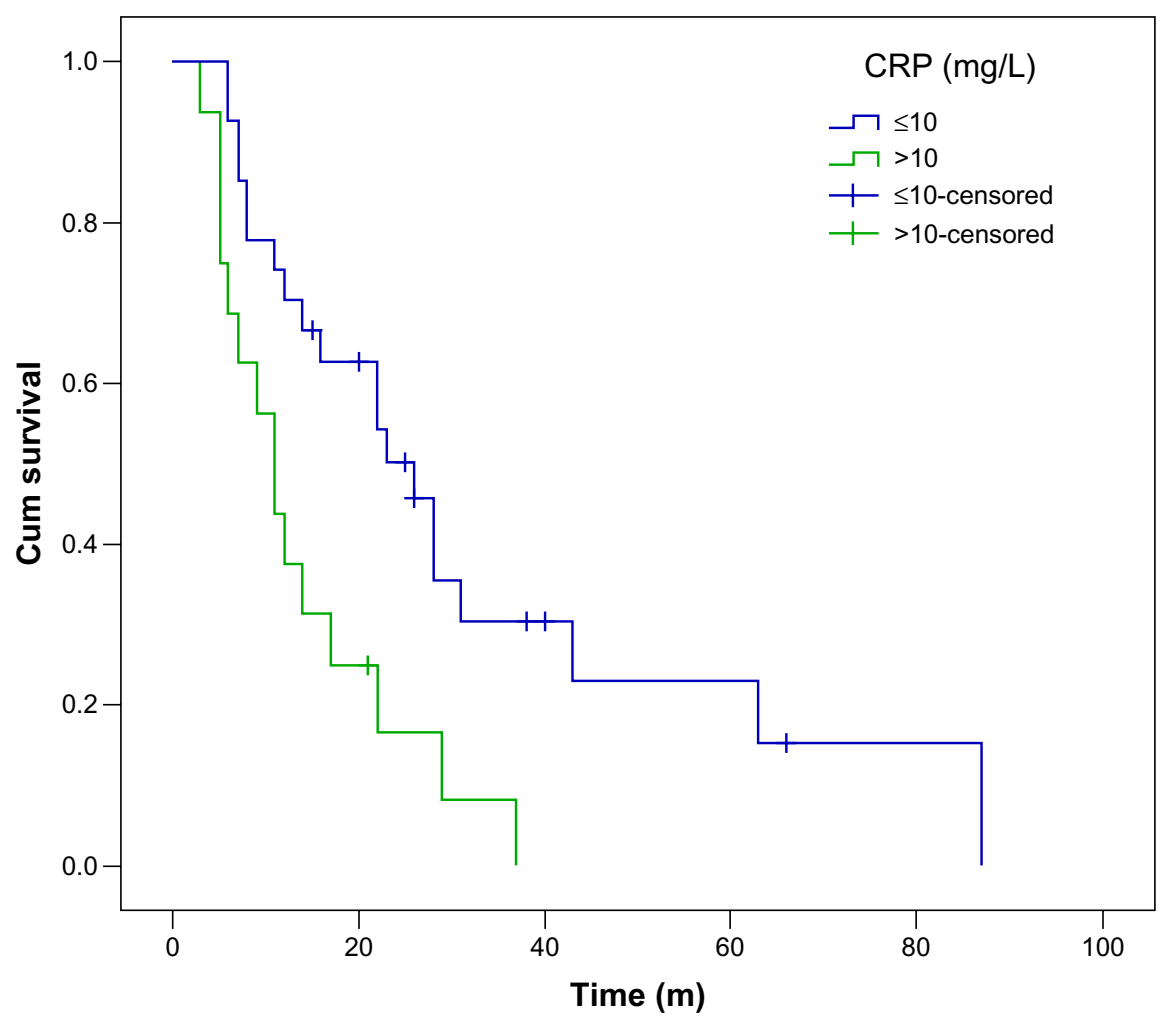

Figure I Patients with CRP $\leq 10 \mathrm{mg} / \mathrm{L}$ had a significantly better 5 -year overall survival rate than patients with $\mathrm{CRP}>10 \mathrm{mg} / \mathrm{L}(25.9 \%$ vs $6.3 \%, P=0.004)$. Abbreviation: CRP, C-reactive protein. 
type II errors. The results of the study should therefore be regarded with caution. In addition, no control population study was undertaken; hence, there are limitations in the scientific observations. Larger prospective studies will need to be performed to confirm these preliminary results.

\section{Conclusion}

Our study showed that preoperative CRP is an independent predictive factor for long-term survival in patients with SCCE. Serum CRP is a simple, reliable, cheap, and reproducible method, for which interpretation is relatively easy in the context of a non-septic neoplasia. We therefore propose pretreatment CRP as a useful adjunct that can be associated in routine practice with pretreatment screening in patients with SCCE.

\section{Acknowledgment}

The authors would like to thank Ms Ying Huang (Department of Nursing, Zhejiang Cancer Hospital) for data collection and statistical analysis.

\section{Disclosure}

The authors report no conflicts of interest in this work.

\section{References}

1. McKeown F. Oat-cell carcinoma of the oesophagus. J Pathol Bacteriol. 1952;64(4):889-891.

2. Koide N, Saito H, Suzuki A, et al. Clinicopathologic features and histochemical analyses of proliferative activity and angiogenesis in small cell carcinoma of the esophagus. $J$ Gastroenterol. 2007;42(12): 932-938.

3. Brenner B, Tang LH, Shia J, Klimstra DS, Kelsen DP. Small cell carcinomas of the gastrointestinal tract: clinicopathological features and treatment approach. Semin Oncol. 2007;34(1):43-50.

4. Balkwill F, Mantovani A. Inflammation and cancer: back to Virchow? Lancet. 2001;357(9255):539-545.
5. Mantovani A, Allavena P, Sica A, Balkwill F. Cancer-related inflammation. Nature. 2008;454(7203):436-444.

6. Nakanishi H, Araki N, Kudawara I, et al. Clinical implications of serum C-reactive protein levels in malignant fibrous histiocytoma. Int J Cancer. 2002;99(2):167-170.

7. Platt JJ, Ramanathan ML, Crosbie RA, et al. C-reactive protein as a predictor of postoperative infective complications after curative resection in patients with colorectal cancer. Ann Surg Oncol. 2012;19(13): 4168-4177.

8. Shimada H, Nabeya Y, Okazumi S, et al. Elevation of preoperative serum C-reactive protein level is related to poor prognosis in esophageal squamous cell carcinoma. J Surg Oncol. 2003;83(4):248-252.

9. Nozoe T, Saeki H, Sugimachi K. Significance of preoperative elevation of serum C-reactive protein as an indicator of prognosis in esophageal carcinoma. Am J Surg. 2001;182(2):197-201.

10. Guillem P, Triboulet JP. Elevated serum levels of C-reactive protein are indicative of a poor prognosis in patients with esophageal cancer. Dis Esophagus. 2005;18(3):146-150.

11. Casas F, Ferrer F, Farrus B, Casals J, Biete A. Primary small cell carcinoma of the esophagus: a review of the literature with emphasis on therapy and prognosis. Cancer. 1997;80(8):1366-1372.

12. Hudson E, Powell J, Mukherjee S, et al. Small cell oesophageal carcinoma: an institutional experience and review of the literature. Br J Cancer. 2007;96(5):708-711.

13. Jatoi A, Miller RC. Should we recommend surgery to patients with limited small cell carcinoma of the esophagus? J Thorac Oncol. 2008;3(12):1373-1376.

14. Vos B, Rozema T, Miller RC, et al. Small cell carcinoma of the esophagus: a multicentre Rare Cancer Network study. Dis Esophagus. 2011;24(4):258-264.

15. Zimmerman MA, Selzman CH, Cothren C, et al. Diagnostic implications of C-reactive protein. Arch Surg. 2003;138(2):220-224.

16. Szalai AJ, VanCott JL, McGhee JR, et al. Human C-reactive protein is protective against fatal Salmonella enterica serovar typhimurium infection in transgenic mice. Infect Immun. 2000;68(10):5652-5656.

17. Szalai AJ, Briles DE, Volanakis JE. Human C-reactive protein is protective against fatal Streptococcus pneumoniae infection in transgenic mice. J Immunol. 1995;155(5):2557-2563.

18. Allin KH, Nordestgaard BG. Elevated C-reactive protein in the diagnosis prognosis, and cause of cancer. Crit Rev Clin Lab Sci. 2011;48(4): $155-170$.

19. Groblewska M, Mroczko B, Sosnowska D, Szmitkowski M Interleukin 6 and C-reactive protein in esophageal cancer. Clin Chim Acta. 2012;413(19-20):1583-1590.
OncoTargets and Therapy

\section{Publish your work in this journal}

OncoTargets and Therapy is an international, peer-reviewed, open access journal focusing on the pathological basis of all cancers, potential targets for therapy and treatment protocols employed to improve the management of cancer patients. The journal also focuses on the impact of management programs and new therapeutic agents and protocols on

\section{Dovepress}

patient perspectives such as quality of life, adherence and satisfaction The manuscript management system is completely online and includes a very quick and fair peer-review system, which is all easy to use. Visit http://www.dovepress.com/testimonials.php to read real quotes from published authors. 